\title{
Multi-item inventory policy with time-dependent pricing and rework cost
}

\author{
Laila Nafisah, Nabilla Clara Devi Maharani, Yuli Dwi Astanti, \\ Muhammad Shodiq Abdul Khannan
}

Department of Industrial Engineering, UPN “Veteran” Yogyakarta

laila@upnyk.ac.id; bellancdm@gmail.com; yuli.upnyk@yahoo.com; shodiq@upnyk.ac.id

*Corresponding Author: laila@upnyk.ac.id

\section{ARTICLE INFO}

\section{Keywords}

Inventory model;

Time dependent pricing;

Multi item;

Rework cost.

\section{Article history}

Received:

July 1,2021

Revised:

July 19, 2021

Accepted:

August 21, 2021

Available online:

August 31, 2021

\section{ABSTRACT}

The price of broiler chickens at the consumer level varies daily. The price can be very low or otherwise. The price has resulted from the imbalance between the availability of chicken from suppliers and the market demand. As a result, demand will also fluctuate because it is influenced by consumer purchasing power. When the price of live chickens is low, the carcass company will usually buy in large quantities and expect to sell them at a higher price. The problem arises when the chicken overstock company will risk product damage due to product buildup in the refrigerated warehouse, so rework is necessary. In this paper, we will be developed a multi-item inventory model that considers material prices that vary to time, probabilistic demand, and rework costs. The aim is to determine the right policy for controlling frozen chicken products' inventory to minimize losses and total inventory costs. This model can evaluate the best time to order broiler chickens, how much to order, how long the interval between orders, and the optimal number of orders, resulting in minimum total inventory cost per period. The model solution is carried out with an optimization approach based on the parameters that affect the model. A numerical example is given at the end of this paper for model validation and illustrates the model solving algorithm.

\section{Introduction}

\subsection{Background}

Management of the inventories is a mandatory activity that any company must do in the best way. Therefore, inventory has become a key challenge for every production manager (Velazqueza \& Barron, 2016). A company should maintain the continuity of its production, one way is to maintain the availability of raw materials (Badri, et al., 2020). A good supply of raw materials will directly guarantee the continuity and timeliness of production. The fulfillment of the supply of raw materials can be obtained by cooperating with companies outside the company's production system. Suppliers have the power to determine the selling price to consumers. The selling price given by the supplier may increase or decrease in a certain period. This situation can be caused by various factors, including changes in community product prices, production technology prices, and irregular trading chains. The selling price given by the supplier to the company will certainly affect the selling price provided by the company to the consumer. As a 
result, demand will also fluctuate because it is influenced by consumer purchasing power. When product prices rise, demand tends to decrease and vice versa. Four potential factors influence pricing decisions: competition, consumer preferences, uncertain demand, and perishable characteristics (Chen, 2018). Consumer decisions to purchase a product depend not only on the retail (or selling) price but also on its reference price (Chenavaz \& Paraschiv, 2018).

The government's policy aimed at breaking the chain of the spread of Covid-19 through LargeScale Social Restrictions is starting to impact the lack of food availability. The supply chain of various commodities, including broiler chicken, is experiencing a serious disturbance (Widiawati, et al., 2020). The survey data conducted in April 2019 showed that the price of live broiler chickens at the farmer level ranges from IDR 7,000 - 8,000 per kg. At the same time, the cost of production at the farmer level is around IDR 18,700 per $\mathrm{kg}$. This situation lasted for several months. As a result, in June 2019, chicken farmers who are members of the Yogyakarta Chicken Farmers Association (APAYO) distributed 6,500 chickens for free. The aim is to reduce stock so that there is a balance between supply and demand and also a strategy to seek more attention from the government on the falling selling price of broilers. Of course, the business actors of chicken pieces also feel the impact. Throughout 2020, along with the Covid-19 pandemic, the broiler industry in the Yogyakarta area experienced ups and downs. The price of broiler chickens in cages reached its lowest point in April at IDR 7,000 per kg. Meanwhile, in early July, the price of broiler chickens soared, reaching IDR 42,000 per kg (PIPRI, 2020).

In the Yogyakarta area, there is a company engaged in the poultry sector. The company partners with farmers to raise broilers on a plasma-core system. One of the products produced by the company is chicken. Broiler chickens are broilers that have been cleaned from their feathers, internal organs, heads, and legs and then cut into several pieces. During this time, the company stores chicken pieces in frozen form to be hygienic and safe for consumption. This method is also considered to be able to extend the life of the product. However, this freezing storage system will certainly lead to significant storage costs and the risk of decreasing quality if the product is stored for a long time.

On the other side, one of the assumptions considered in old inventory models was that all items should maintain the physical characteristics when they are stored in the warehouse. Nonetheless, mass storage of perishable goods in the warehouse, especially once they begin to lose their quality, results in continuous loss or performance deterioration, corrosion damage, waste, and penalties for suppliers. Considering these facts, controlling and maintaining warehouse with perishable goods is a challenging problem for decision-makers (Khorasani \& Almasifard, 2017).

Variations on the price of broiler chickens at the supplier level, which are significant daily, make the company find it difficult to determine policies to control the inventory of its products. To anticipate significant fluctuations in broiler prices, the company takes a strategy: whenever the price of broiler chickens at the supplier level is low, the company will buy in large quantities in the hope of selling their products at a higher market price on the following days. As a result, the stock of chicken products stored in the refrigerated warehouse becomes excessive. Another effect is product damage. It is because the storage is stacked without using a barrier in each storage package. Inventories in the warehouse are stored in a frozen state, but still can be broken and or bruised in some vulnerable parts.

To overcome products damaged by storage, the company does rework to have a selling value still. The rework process is carried out by cutting the damaged parts of the product, and discarded. The reworked product can be resold, but the selling price decreases due to size changes and 
does not qualify the excellent quality product categories. This step is considered more profitable because the damaged product still has a selling value so that the company does not suffer a more significant loss. On average, the percentage of rework products is still quite high, which is around $2.81 \%$, while the maximum rework target is $1 \%$. If there is no follow-up on this matter, it is feared that the company will experience more significant losses. Therefore, it is essential to find a solution to avoid even more significant losses.

\subsection{The Problem}

The imbalance between the availability of broiler chickens from suppliers and market demand causing chicken prices to fluctuate. As a result, the company carries out a strategy of buying in large quantities when the price of broiler chickens is low and hopes to sell it at a higher price the next days. The problem emerges when the inventory is overstocked, there will be a risk of product damage due to product buildup in the refrigerated warehouse. The company repairs them by rework to deal with damaged products, namely removing damaged or bruised parts. The existence of rework causes losses due to the wasting of damaged/bruised chicken parts and the cost of rework operations.

\subsection{Proposed Solution}

This paper develops a multi-item inventory model that considers material prices that vary with time, probabilistic demand, and rework costs based on the previous passage. The aim is to determine the policy for controlling the inventory of frozen carcass chicken products to minimize losses and the total inventory cost incurred.

The research result has benefit for company to determine the policy of controlling the inventory of frozen carcass chicken products. By optimizing order quantity and time between orders in the procurement of broiler raw materials so that stockpiling can be avoided, company losses due to rework activities can be minimized, and it is expected that the total Inventory costs incurred.

\section{Literature Review}

Several researchers have carried out research on inventory control models by considering intensive rework policies. Utama et al. (2019) developed an Economic Production Quantity (EPQ) model by considering the rework process and warehouse constraints, the assumption used is that imperfect products can be reworked. Octavia et al. (2020) have also developed a model of EPQ that considers continuous demand, discrete, and rework simultaneously. This model produces optimal production times for inventory systems with continuous and discrete demand and accommodates policies to rework products that do not meet quality standards. There is a probability of increasing the number of productions per cycle of production time. In addition, Islam et al. (2018) has developed a stochastic inventory model by considering rework using the Markov process. There are two models produced. The first model is an inventory model for non-perishable goods that allows for returns and is followed up with rework. Then, the second model is an inventory model for perishable goods.

An inventory model for an imperfect production system with rework and shortages also has been developed by Sanjai and Periyasamy (2019). Several other researchers who have also developed models related to imperfect products and rework are Chiu et al. (2014) and Chiu et al. (2015) studied the optimal common production cycle policy for a multi-item EPQ model with scrap, rework, and multiple deliveries. Nobil et al. (2019) introduce an EPQ problem for an imperfect 
manufacturing system with non-zero setup times for rework items. Salamah (2016) develops an EPQ model for the case where the production process and inspection are both not perfect. Rahman et al. (2016) have developed two mathematical models which incorporate two transportation modes. And Leuveano et al. (2019) developed an integrated vendor-buyer lotsizing model by considering transportation and quality improvements into a JIT environment. Whereas Taheri and Mirzazadeh (2021) research a new approach was applied to a single-item single source system considering imperfect items and uncertain environment. They study the optimization of the inventory system with defects, rework failure, and two types of errors under a crisp and fuzzy approach.

Determining the optimal order policy and selling price is usually treated as a separate issue, but it is more useful to consider them together. If the purchase price is time-dependent and is currently high, it may be advantageous to increase the selling price so that when all sold-out inventory is delayed. It increases the probability that the procurement price of new items decreases, so new items can be ordered at considerably lower costs (Boer et al., 2017). So that the effect of price fluctuations on optimal inventory control policy can be considerable (Bachman, 1986). The studies on economic ordering policy for a product with periodic price changes has been presented by Goyal, 1984. And then Goyal and Barron (2002) also investigated a simple efficient solution procedure to distinguish EPQ for imperfect production. Research on inventory control models that consider price fluctuations also has been carried out by Muhammad and Arvianto (2015). This study discusses the control of multi-item inventory for packaging made from paper rolls which consider fluctuations in demand and prices of goods. Zheng et al. (2020) studies a supply chain ordering problem for two level price-fluctuation sales and establishes a bilevel programming model by Copula function measuring the correlation between price and demand.

Because basic commodities are needed throughout the year, the availability of them are crucial. To maintain food security in Indonesia, one way to overcome this problem is to provide a buffer supply as an instrument to control the balance of supply and market demand. Therefore, Jenar et al. (2015) developed a game theory model on the buffer supply scheme to ensure the availability and stability of commodity prices. The results show that the game theory model can describe the transaction relationship between producers and consumers in a buffer inventory scheme. In addition, game theory can describe several conditions in the buffer supply scheme through the developed strategy. While Arnold et al. (2009) presents a deterministic optimal control approach optimizing the procurement and inventory policy of an enterprise that is processing a raw material when the purchasing price, holding cost, and the demand rate fluctuate over time. Applying Pontryagin's maximum principle, the optimal policy turns out to be of a bang-bang type involving impulse and just in-time procurement.

In previous studies, the developed model has not considered fluctuating prices and rework costs simultaneously. Based on the problems faced in the broiler company, this study will develop a multi-item inventory control model that considers price fluctuations and the rework costs. The price fluctuations in the study are the prices of raw materials. It can arise due to changes in the price of community products, the price of production technology, and the occurrence of an irregular trading chain, while rework costs are a consequence of the steps taken by the company in dealing with damaged products, as a result of excess inventory. The objective function of this research is to minimize the expected total cost of inventory per year. Expected total inventory cost consist of expected purchase cost, expected ordering cost, expected holding cost, and expected rework cost. While the model to be developed in this study refers to the model of Muhammad \& 
Arvianto (2016) and Arnold et al. (2009) by considering the rework factor which is adjusted to conditions in the real system.

\section{Model Development}

\subsection{Notations and assumptions}

The parameter notation used in this model is as follows:

$p(t)$ : the expected purchase price of goods per unit

$p \quad$ : the price of goods per unit

$f(p)$ : probability mass function of price

$x(t)$ : expectations of goods to be purchased during period $\mathrm{t}$

$A \quad$ : ordering cost per order

$h(t)$ : holding cost per unit per period $t, h(t)=I \cdot p(t)$

$R \quad$ : rework cost

$m(t)$ : expected on-hand inventory level per period $\mathrm{t}$

$S S \quad$ : safety stock

$S_{L} \quad$ : standard deviation during lead time

$z_{\alpha} \quad$ : safety factor, a standard normal random variable with a safety level of $(1-\alpha)$

$D \quad:$ demand rate

$\beta \quad$ : percentage of defect products

$Q \quad$ : order quantity per cycle

$T \quad$ : order interval per cycle

$i \quad$ : item type $(\mathrm{i}=1,2, \ldots, \mathrm{n})$

$P C \quad$ : expected purchase cost per period $\mathrm{t}$

$O C$ : expected ordering cost per period $t$

$H C$ : expected holding cost per period $\mathrm{t}$

$R C \quad$ : expected rework cost per period $\mathrm{t}$

$T C$ : expected total cost of inventory per period $t$

The assumptions used in this study are as follows:

1) Demand for items is normally distributed

2) The prices of raw materials are variable

3) All demands can be satisfied

4) Lead time constant

5) Broiler chickens that come directly are produced into frozen chicken pieces

6) Weight loss from live broilers to frozen chicken products by $15 \%$

\subsection{Mathematical model}

This research develops a multi-item inventory model that considers material prices that vary with time, probabilistic demand, and rework cost. This model is based on a case study in a frozen chicken company in Yogyakarta. The aim is to determine the right policy for controlling the inventory of frozen carcass chicken products to minimize losses and the total inventory cost incurred. The basic model used in the development of this model is the model of Muhammad \& Arvianto (2016) and Arnold et al. (2009). In this model, an inventory model has been developed that considers the fluctuating prices of goods. 
The objective function of this research is to minimize the expected total cost of inventory per period t. Expected total inventory cost consist of expected purchase cost, expected ordering cost, expected holding cost and expected rework cost.

1) Expected purchase cost per period

The expected purchase cost of goods is the multiplication of the expected price of goods per unit with the expectation of goods purchased during period t.

$P C=\int_{0}^{T} p(t) x(t) d t$

While,

The expected price of goods per unit, $p(t)$, is affected by the probability mass function of the price, $f\left(p_{j}\right)$, and the random variable of price during period $t, p_{j}(t)$.

$p(t)=\sum_{j=1}^{m} p_{j}(t) f\left(p_{j}\right)$

2) Expected ordering cost per period

The expected ordering cost during period $t$ is

$O C=\int_{0}^{T} \frac{A}{T} d t$

3) Expected holding cost per period

The expected holding cost per period t depends on the unit holding cost per period and the expected of on hand inventory level per period $t$

The expected holding cost of item i during period $t$ is

$H C_{i}=\int_{0}^{T} h_{i}(t) m_{i}(t) d t$

The expected holding cost of $\mathrm{n}$ item during period $\mathrm{t}$ is

$H C=\sum_{i=1}^{n} \int_{0}^{T} h_{i}(t) m_{i}(t) d t$

While,

$h_{i}(t)=I \cdot p_{i}(t)$

$m_{i}(t)=\frac{x_{i}(t) T}{2}+S S_{i}$

Then, 


$$
H C=\sum_{i=1}^{n} \int_{0}^{T}\left(h_{i}(t) \frac{x_{i}(t) T}{2}+S S_{i}\right) d t
$$

4) Expected rework cost per period

The rework cost per period t depends on the amount of rework cost per one rework, the percentage of rework products and the expected product demand per period $t$

$$
R C=\beta \frac{R}{T} \sum_{i=1}^{n} D_{i}
$$

The expected total cost of inventory per period $\mathrm{t}$

$$
T C=P C+O C+H C+R C
$$

$T C=\int_{0}^{T} p(t) x(t) d t+\int_{0}^{T} \frac{A}{T} d t+\sum_{i=1}^{n} \int_{0}^{T}\left(h_{i}(t) \frac{x_{i}(t) T}{2}+S S_{i}\right) d t+\beta R \sum_{i=1}^{n} D_{i}$

To get the optimal time interval between orders, the expected total inventory cost is differentiated with respect to $T$ such that it is equal to zero.

$\frac{\partial T C}{\partial T}=0$

$T^{*}=\sqrt{\frac{2 \int_{0}^{T} A d t}{\sum_{i=1}^{n} \int_{0}^{T} x(t) h_{i}(t) d t}}$

The calculation of raw materials purchase quantity is calculated using the purchase model proposed by Arnold et al. (2007). This equation is a function of maximizing the demand that exists between the starting point of goods being stored or the starting point of goods that will experience destocking in $T$ period $\left(t_{n}^{J D}\right)$ and the endpoint of procurement or restocking $\left(t_{n+1}^{D J}\right)$ minus the storage $y_{i}$ that exists at the starting point of destocking. Therefore, the equation for the optimal purchase quantity is written as follows:

$Q_{i}\left(t_{n}^{D J}\right)=x(t)=($ the demand that exists in a period $)-($ inventory on hhand in period $)$

$Q_{i}\left(t_{n}^{D J}\right)=x_{i}(t)=\max \left\{\int_{t_{n}^{J D}}^{t_{n+1}^{D J}} D_{i}(u) d u-y_{i} t_{n}^{J D} ; 0\right\}$

As a result of the assumption in number 6 , then the demand for broilers during the planning horizon is

$x(t)=\frac{100}{85} \sum_{i=1}^{n} x_{i}(t)$ 
While the optimal ordering quantity of broiler chickens per cycle $T^{*}$ are

$Q^{*}=x(t) \cdot T^{*}$

The amount of safety stock is

$S S_{i}=z_{\alpha .} S_{i_{L}}$

\subsection{Model Solution}

The solution procedure used in solving the developed model is as follows:

(1) Determine the probability mass function of a random variable of broiler prices based on historical data

(2) Calculate the expected value of broiler prices using equation (2)

(3) Calculate the expected quantity of broiler chicken purchases using equation (12) and (14)

(4) Calculate the time between orders for broiler chickens using equation (11)

(5) Calculate the optimal production quantity of item i using equation (15)

(6) Calculate the safety stock by determining the standard deviation of demand during the lead time and the safety factor first using equation (16)

(7) Calculate the expected total purchase cost of all items per period using equation (1)

(8) Calculate the expected total ordering cost per period using equation (3)

(9) Calculate the expected total holding cost per period using equation (8)

(10) Calculate the expected total rework cost per period using equation (9)

(11) Calculate the expected total inventory cost per period using equation (10)

\section{Results and Discussion}

An example of a numerical calculation used to illustrate a model completion algorithm, considering two types of products. As for other data are as follows:

$A=210,700$ per order, $h=1,400$ per $\mathrm{kg} /$ period, $D_{1}=1,023,846 \mathrm{~kg}, D_{2}=37,271.5 \mathrm{~kg}$, $y_{1}=80,000 \mathrm{~kg}, y_{2}=500 \mathrm{~kg}, \beta=0.026, R=1,800 / \mathrm{kg}$, lead time 1 day, $95 \%$ of service level, and planning horizon four months.

To determine the expected value of the price per unit of goods, the probability mass function is first determined from the random variable price based on historical data. The results obtained are $p(t)=16,309$ per $\mathrm{kg}, x_{1}(t)=943,846 \mathrm{~kg}, x_{2}(t)=36,771.5 \mathrm{~kg}, x(t)=1,153,667.6 \mathrm{~kg}$, $T^{*}=0.018, Q^{*}=17,167 \mathrm{~kg} / \mathrm{order}, S S_{1}=811.5 \mathrm{~kg}, S S_{2}=49.4 \mathrm{~kg}$, and $T C=16,707,881,600$ per 4 months.

Sensitivity analysis is a classical method used to analyze the impact of parameters on model output, and sensitivity analysis is required Leuveano (2019). This paper uses sensitivity analysis to investigate how much variation in cost parameters impacts the solution and the total cost. Sensitivity analysis was carried out on the resulting model formulation, which was carried out by changing (adding or subtracting) some of the existing parameter values from $-25 \%$ to $+25 \%$. This is to see the effect that will occur from changes in the value of these parameters on the total inventory cost.

The recapitulation of the calculation results in this sensitivity analysis can be seen in Table 1. And the results of the sensitivity analysis are as follows:

1) Raw material prices, $p(t)$. Changes in raw material prices do not affect to $Q^{*}$ and $T^{*}$. However, changes in raw material prices provide a significant change to $T C$. It is because the price of raw materials will affect the expected purchase costs for the overall raw material 
requirements during the planning period. The expectation of purchasing costs will then affect the expectations of total inventory costs. The greater the expected purchase costs incurred, the greater the expectations of the company's total inventory costs.

2) Ordering cost, $A$. Change in the ordering cost parameter affects to $Q^{*}, T^{*}$, and $T C$. In the decision variable of the ordering period, it can be seen that the smaller the ordering cost, the company will need a shorter time to place an order. Meanwhile, the greater the ordering cost, the longer the time interval for the company to place an order. Then on the decision variable, the ordering quantity is also directly proportional to the ordering cost. The smaller the ordering cost, the smaller the order quantity will be because the company will place an order more often. Although the changes given are not too significant, they still provide a reasonably large difference in value.

3) Holding cost, $h$. Change in the storage cost parameter causes a change in the decision variables $Q^{*}, T^{*}$, and $T C$. The smaller the storage cost, the larger the order quantity will be, so the company's time interval will be longer. With an increase in ordering costs, the expectation of total ordering costs tends to increase as well. Although the changes are not too significant, they provide a large change in value.

4) Rework cost, $R$. Changes in rework costs affect to $T C$, but do not affect to $Q^{*}$ and $T^{*}$. The effect of rework costs resulted in a significant difference in TC. This is because the cost of rework will affect the amount of rework costs. The cost of rework will affect the expected total cost of inventory, the greater the cost of rework, the greater the total cost of the company's inventory.

Table 1. Recapitulation of sensitivity analysis calculations

\begin{tabular}{|c|c|c|c|c|c|r|}
\hline \multirow{3}{*}{ Parameter } & $\Delta \%$ & $\sum_{i=1}^{n} \boldsymbol{x}_{\boldsymbol{i}}(\boldsymbol{t})$ & $\boldsymbol{T}^{*}$ & $\boldsymbol{Q}$ & TC & $\% \Delta$ TC \\
\hline \multirow{4}{*}{$\boldsymbol{p}(\boldsymbol{t})$} & $-25 \%$ & $1,153,667.6$ & 0.018 & $17,167.0$ & $12,717,977,500$ & -23.880 \\
\cline { 2 - 7 } & $-10 \%$ & $1,153,667.6$ & 0.018 & $17,167.0$ & $15,111,920,000$ & -9.552 \\
\cline { 2 - 7 } & $10 \%$ & $1,153,667.6$ & 0.018 & $17,167.0$ & $18,303,843,400$ & 9.552 \\
\cline { 2 - 7 } & $25 \%$ & $1,153,667.6$ & 0.018 & $17,167.0$ & $20,697,785,900$ & 23.880 \\
\hline \multirow{4}{*}{$\boldsymbol{A}$} & $-25 \%$ & $979,117.6$ & 0.015 & $14,867.3$ & $16,714,888,000$ & 0.042 \\
\cline { 2 - 7 } & $-10 \%$ & $979,117.6$ & 0.017 & $16,286.3$ & $16,715,881,300$ & 0.048 \\
\cline { 2 - 7 } & $10 \%$ & $979,117.6$ & 0.018 & $18,005.2$ & $16,717,084,500$ & 0.055 \\
\cline { 2 - 7 } & $25 \%$ & $979,117.6$ & 0.020 & $19,193.6$ & $16,717,916,400$ & 0.060 \\
\hline \multirow{4}{*}{$\boldsymbol{h}$} & $-25 \%$ & $979,117.6$ & 0.020 & $19,823,0$ & $16,543,241,000$ & -0.985 \\
\cline { 2 - 7 } & $-10 \%$ & $979,117.6$ & 0.018 & $18,095.9$ & $16,647,222,500$ & -0.363 \\
\cline { 2 - 7 } & $10 \%$ & $979,117.6$ & 0.017 & $16,368.3$ & $16,785,743,200$ & 0.466 \\
\cline { 2 - 7 } & $25 \%$ & $979,117.6$ & 0.016 & $15,354.9$ & $16,889,563,300$ & 1.087 \\
\hline \multirow{4}{*}{$\boldsymbol{R}$} & $-25 \%$ & $979,117.6$ & 0.018 & $17,167.2$ & $16,695,466,600$ & -0.074 \\
\cline { 2 - 7 } & $-10 \%$ & $979,117.6$ & 0.018 & $17,167.2$ & $16,702,915,700$ & -0.030 \\
\cline { 2 - 7 } & $10 \%$ & $979,117.6$ & 0.018 & $17,167.2$ & $16,712,847,700$ & 0.030 \\
\cline { 2 - 7 } & $25 \%$ & $979,117.6$ & 0.018 & $17,167.2$ & $16,720,296,800$ & 0.074 \\
\hline
\end{tabular}




\begin{tabular}{|c|c|c|c|c|c|r|}
\hline \multirow{3}{*}{ Parameter } & $\Delta \%$ & $\sum_{i=1}^{n} \boldsymbol{x}_{\boldsymbol{i}}(\boldsymbol{t})$ & $\boldsymbol{T}^{*}$ & $\boldsymbol{Q}$ & $\mathbf{T C}$ & \% $\Delta$ TC \\
\hline \multirow{4}{*}{$\boldsymbol{\beta}$} & $-25 \%$ & $979,117.6$ & 0.018 & $17,167.2$ & $16,695,466,600$ & -0.074 \\
\cline { 2 - 7 } & $-10 \%$ & $979,117.6$ & 0.018 & $17,167.2$ & $16,702,915,700$ & -0.030 \\
\cline { 2 - 7 } & $10 \%$ & $979,117.6$ & 0.018 & $17,167.2$ & $16,712,847,700$ & 0.030 \\
\cline { 2 - 7 } & $25 \%$ & $979,117.6$ & 0.018 & $17,167.2$ & $16,720,296,800$ & 0.074 \\
\hline \multirow{5}{*}{$\boldsymbol{y}_{\mathbf{1}}$} & $-25 \%$ & $999,117.6$ & 0.017 & $17,341.7$ & $17,048,003,800$ & 2.036 \\
\cline { 2 - 7 } & $-10 \%$ & $987,117.6$ & 0.017 & $17,237.2$ & $16,843,930,700$ & 0.814 \\
\cline { 2 - 7 } & $10 \%$ & $971,117.6$ & 0.018 & $17,097.0$ & $16,571,832,500$ & -0.814 \\
\cline { 2 - 7 } & $25 \%$ & $959,117.6$ & 0.018 & $16,991.0$ & $16,367,758,300$ & -2.036 \\
\hline \multirow{3}{*}{$\boldsymbol{y}_{\mathbf{2}}$} & $-25 \%$ & 979617.590 & 0.0175 & $17,171.6$ & $16,716,384,800$ & 0.051 \\
\cline { 2 - 7 } & $-10 \%$ & 979317.590 & 0.0175 & $17,169.0$ & $16,711,282,900$ & 0.020 \\
\cline { 2 - 7 } & $10 \%$ & 978917.590 & 0.0175 & $17,165.5$ & $16,704,480,500$ & -0.020 \\
\cline { 2 - 7 } & $25 \%$ & 978617.590 & 0.0175 & $17,162.9$ & $16,699,378,600$ & -0.051 \\
\hline
\end{tabular}

5) The proportion of defects, $\beta$. Changes in the proportion of defects affect to $T C$, but do not affect to $Q^{*}$ and $T^{*}$. The proportion of defects affects the cost of rework, while the cost of rework affects the total inventory cost. The more significant the proportion of defects, the greater the rework cost, so the total cost of the company's inventory will be more significant.

Generally, it can be explained that the changes in the parameters $p(t), A, h, R, \beta, y_{1}$, and $y_{2}$ the value of the decision variables $T^{*}$ did not change significantly. However, the changes in the value of $A, h, y_{1}$, and $y_{2}$ the changes are quite significant to the value of $Q^{*}$ and $T C$, so it is said that the model is sensitive to these changes, the solution is that the model must change to accommodate changes in these parameters.

Sensitivity analysis can be defined as the study of how uncertainty in a model's output can be apportioned to different sources of uncertainty in the model input (Saltelli, et al., 2008). The aim is to identify the primary sources of uncertainty (Saltelli \& Annoni, 2010). Therefore, sensitivity analysis is important to see the sensitivity of the model to uncertainty in parameters (Qian \& Mahdi, 2020).

\section{Conclusion}

The imbalance between the availability of broiler chickens from suppliers and market demand causes chicken prices to fluctuate. Companies speculated to make purchases in large quantities when prices were low turned out to be causing a new problem, namely inventory overstock and risking damage when stored, so it needed to be reworked.

This paper develops a multi-item inventory model that considers broiler prices that vary to time, probabilistic demand, and rework costs. The aim is to determine the right policy for controlling the inventory of frozen carcass chicken products to minimize losses and total inventory costs incurred. The model solution is carried out with an optimization approach based on the parameters that affect the model. Through this model, the company can determine when is the best time to order broiler chickens, how much to order, how long the interval between orders is, and the optimal number of orders so that the total inventory cost per period incurred is incurred minimum. 
However, the company needs to be careful in storing carcass chicken products in a cold warehouse. Otherwise, it could result in defective products and needs to be reworked. High rework intensity will result in high rework costs and ultimately will increase the total inventory cost. Profit maximization is one of the ultimate goals of business organizations. To minimize losses due to damaged products, the rework process is one of the efforts that can be done. The rework process may slightly increase the system's total cost, but it has a great effect on branding image in the long run. So the rework process is an essential factor for item guarantee benefit. Without having such facilities, a business firm will lose a significant share of net revenue (Islam et al., 2018). The sensitivity analysis results provide helpful insights to assist companies in addressing critical parameters that affect the solution and total cost performance.

For further research, several possible extensions can be considered for this model. Among them is the need to consider the expiration of stored products, stockouts, limited storage space, integration between buyers and vendors, etc.

\section{References}

Velazqueza, E.A.P. \& Barron, L.E.C. (2016). An Economic Production Quantity Inventory Model with Backorders Considering the Raw Material Costs. Scientia Iranica, 23(2), 736-746.

Badri, H.M., Khamis, N.K., \& Ghazali, M.J. (2020). Integration of lot sizing and scheduling models to minimize production cost and time in the automotive industry. International Journal of Industrial Optimization, 1(1), 1-14.

Chen, W., Liu, H. \& Xu, D. (2018). Dynamic Pricing Strategies for Perishable Product in a Competitive Multi-Agent Retailers Market. Journal of Artificial Societies and Social Simulation, 2(12).

Chenavaz, R. \& Paraschiv C. (2018). Dynamic pricing for inventories with reference price effects. Economics Discussion Papers, No 2018-50.

Widiawati, I., Sumiati, T. \& Hardyanti, P.I. (2020). Analisis Rantai Pasok Telur Ayam Ras pada Masa Pandemi Covid-19 pada Kelompok Usaha Peternakan Ayam Ras Petelur Gallus Jaya di Desa Setiawaras Kecamatan Cibalong Kabupaten Tasikmalaya. Prosiding Seminar Nasional Polbangtan Magelang, ISBN: 978-623-95866-03, 156-166.

Perhimpunan Insan Perunggasan Rakyat Indonesia (PIPRI), Daerah Istimewa Yogyakarta. (2020). https://pinsarindonesia.com.

Khorasani, S.T., \& Almasifard, M. (2017). An Inventory Model with Quantity Discount Offer Policy for Perishable Goods in the Two-Level Supply Chain. International Journal of Engineering and Technology, 9(4), 2828-2834.

Muhammad, R., \& Arvianto, A. (2016). Implementasi Model Persediaan Probabilistik Multi Item dengan Mempertimbangkan Fluktuasi Permintaan dan Harga Barang (Studi Kasus: PT Purinusa Eka Persada). Industrial Engineering Online Journal, 4(1). 
Taleizadeh, A.A., Kalantari, S.S., \& Barrón, L.E.C. (2016). Pricing and lot sizing for an EPQ inventory model with rework and multiple shipments, TOP, 24, 143-155.

Islam, M.E., Uddin, M.S., \& Ataullah, M. (2018). Stochastic Inventory Model with Reworks. Yugoslav Journal of Operations Research, 28(4), 567-578.

Utama, D.M., Wardani, D.P., Halifah, S.T., \& Pradikta, D.C. (2019). Model Economic Production Quantity dengan Rework Process and Batasan Gudang, Jurnal Sistem dan Manajemen Industri, 3(1), 43-49.

Oktavia, N., Henmaidi, \& Fithri, P. (2020). Pengembangan Model Economic Production Quantity Mengakomodasi Continue dan Discrete Demand serta Kebijakan Rework Secara Simultan. Inventory-Industrial Vocational e-Journal on Agroindustry, 1(1), 8-15.

Chiu, Y.S. Wu, M.F., Chiu, S., \& Chang, H.H. (2015). A simplified approach to the multi-item economic production quantity model with scrap, rework, and multi-delivery. Journal of Applied Research and Technology, 13(4), 472-476.

Chiu, S.W., Tseng, C.T., Wu, M.F., \& Sung, P.C. (2014). Multi-item EPQ model with scrap, rework and multi-delivery using common cycle policy. Journal of Applied Research and Technology, $12,615-622$.

Leuveano, R.A.C., Rahman, M.N.A., Mahmood, W.M.F.W., \& Saleh, C. (2019). Integrated Vendor-Buyer Lot-Sizing Model with Transportation and Quality Improvement Consideration under Just-in-Time Problem. Mathematics, 7(10), 1-25.

Rahman, M.N.A., Leuveano, R.A.C., Jafar, F.A.B., Saleh, C., Deros, B.M., Mahmood, W.M.F.W., \& Mahmood, W.H.N.W. (2016). Incorporating Logistic Costs into a Single Vendor-Buyer JELS Model. Applied Mathematical Modelling, Elsevier, 40(23), 10809-10819.

Salamah, M.A. (2016). Economic Production Quantity in Batch Manufacturing with Imperfect Quality, Imperfect Inspection, and Destructive and Non-Destructive Acceptance Sampling in a Two-Tier Market. Computers \& Industrial Engineering, 93, 275-285.

Bachman, (1986). Inventory Control with Price Fluctuations, International Journal of Operations \& Production Management, 6(3), 58-64.

Zheng, M., Meng, Z., \& Shen, R. (2020). Research on Two-Level Price-Fluctuation Supply Chain Ordering Strategy Problem. Discrete Dynamics in Nature and Society, 2020, 1-14.

Jenar, M., Sutopo, W., \& Yuniaristanto. (2015). Pengembangan Model Game Theory Pada Skema Persediaan Penyangga Untuk Menjamin Ketersediaan dan Kestabilan Harga Komoditas Gula Pasir. Jurnal Teknik Industri, 10(2), 97-102.

Arnold, J., Minner, S., \& Eidam, B., (2009). Raw Material Procurement with Fluctuating Prices. International Journal of Production Economic, Elsevier, 121(2), 353-364. 
Boer, A.D., Perry, O. \& Zwart, B. (2017). Dynamic Pricing Policies for an Inventory Model with Random Windows of Opportunities. Naval Research Logistics, Wiley Periodicals, Inc.

Nobil, A.H., Sedigh, A.H.A., Tiwari, S., \& Wee, H.M. (2019). An imperfect multi-item singlemachine production system with shortage, rework, and scrap considering inspection, dissimilar deficiency levels, and non-zero setup times. Scientia Iranica E, 26(1), 557-570.

Goyal, S. K. (1984). Economic ordering policy for a product with periodic price changes. Proceeding Third International Symposium Inventory, Budapest, Hungry.

Goyal S. K., \& Barron, L. E. C. (2002). Note on: Economic production quantity model for items with imperfect quality - a practical approach, International Journal of Production and Economic, 77 (2002), 85-87.

Taheri J., and Mirzazadeh, A. (2021). Optimization of Inventory System with Defects, Rework Failure and Two Types of Errors under Crisp and Fuzzy Approach. Journal of Industrial and Management Optimization, 68.

Saltelli, A., Ratto, M., Andres, T., Campolongo, F., Cariboni, J., Gatelli, D., Saisana, M., \& Tarantola, S. (2008). Global Sensitivity Analysis: the primer. John Wiley.

Saltelli, A., \& Annoni, P. (2010). How to avoid a perfunctory sensitivity analysis. Environmental Modelling \& Software, 25(12):1508-1517.

Qian, G., \& Mahdi, A. (2020, January, 12). Sensitivity analysis methods in the biomedical sciences. arXiv:2001.03965v1 [q-bio.QM]. https://arxiv.org/pdf/2001.03965.pdf. 
This page is intentionally left blank. 